\title{
Influence of joint application of heavy metals on level of each metal accumulated in the periwinkle Tympanotonus fuscatus (Gastropoda: Potamididae)
}

\author{
A.A. Otitoloju* \& K.N. Don-Pedro \\ Environmental Toxicology Laboratory, Department of Zoology, Faculty of Science, University of Lagos, Akoka, \\ Lagos, Nigeria. \\ * Correspondence author: bayotitoloju@yahoo.com
}

Received 23-V-2005. C Corrected 23-I-2006. Accepted 23-V-2006.

\begin{abstract}
Most laboratory assessments of toxicity and bioaccumulation of heavy metals have been concentrated on the accumulation of these metal ions when exposed singly to the test organisms. However, under the natural environmental settings, the metals are never present in isolation and may interact with each other, therefore justifying the need to study the influence of joint application of metals on accumulated levels in exposed animals. In this study, exposure of the periwinkle Tympanotonus fuscatus to sublethal concentrations (equivalent to 0.1 and 0.01 of $96 \mathrm{~h} \mathrm{LC}_{50}$ ) of heavy metals revealed that they were bioaccumulative varying amounts, depending on the type of metal, exposure period and concentration in the test media. While $\mathrm{Zn}$ and $\mathrm{Pb}$ ion accumulation increased steadily with exposure time, the amounts of $\mathrm{Cu}$ accumulated fluctuated regularly over the 30-day experimental period. The levels of $\mathrm{Zn}, \mathrm{Cu}$ and $\mathrm{Cd}$ bioaccumulated over the 30-day experimental period were reduced by over 2-6 folds (with bioaccumulation ratio values ranging from 0.15 to 0.81 ) when compared to concentrations of the respective metals accumulated during single bioaccumulation studies. However, $\mathrm{Pb}$ concentrations accumulated during the joint action studies increased nearly 2-fold (bioaccumulation ratio range 1.36 to 2.0-fold). Rev. Biol. Trop. 54 (3): 803-814. Epub 2006 Sept. 29.
\end{abstract}

Key words: bioaccumulation, joint action, metals, antagonism, synergism.

In many cases, heavy metals occur in natural bodies of water at levels below their toxic thresholds, however, due to their nondegradable nature, such low concentrations may still pose risk of damage via uptake and subsequent bioaccumulation by organisms, which cannot effectively metabolize and excrete the absorbed metals. Several scientific observations have shown that heavy metals are bioconcentrated or bioaccumulated in one or several compartments across food webs (Bryan and Langston 1992, Kiffney and Clement 1993, Oyewo 1998, Otitoloju and Don-Pedro 2003). Metal bioaccumulation can be of importance from the public health point of view, especially when a human consumes the accumulators. Secondly, this phenomenon is now being exploited in the assessment of environmental quality, in addition to chemical surveys of water and sediment. The inclusion of bioaccumulators in a biological monitoring programmed is particularly advantageous since such organisms are known to accumulate these pollutants to levels several folds higher than the amount in the external medium, demonstrating how biological systems can render unsafe, the otherwise low and apparently safe prevalent ambient levels of persistent pollutants in ecosystems (Otitoloju and Don-Pedro 2004).

Most laboratory assessments of toxicity and bioaccumulation of heavy metals have been concentrated on the accumulation of these metal ions when exposed singly to the test organisms (Panigrahi and Misra 1980, Wright et al. 1991, Sastry and Shukla 1993, Oyewo 1998). However, under the natural 
environmental settings in the field, the metals are never present in isolation and may interact with each other as a result of competition for binding sites in the exposed animal tissues or may form complexes which may or may not be easily excreted (Wright and Zamuda 1987, Otitoloju 2002, 2003). These interactions between the metals may lead to either a decrease or an increase in their individual uptake/excretion (Franklin et al. 2002). It is therefore important to establish the effects of the joint presence of the major types of heavy metals on their rate and subsequent level of bioaccumulation in aquatic organisms such as Tympanotonus fuscatus (periwinkle), which is a delicacy amongst the people inhabiting the coastal areas in Nigeria. This type of study may also provide an insight into the mechanisms of antagonism, synergism or additive action, which are observed when test organisms are exposed to the toxic effects of heavy metals in joint action toxicity studies.

\section{MATERIALS AND METHODS}

Test animals: $T$. fuscatus var radula L. (periwinkle, Mollusca; Gastropoda, Mesogastropoda, Potamididae) of similar sizes (shell length of 28 to $32 \mathrm{~mm}$ ) was collected by handpicking into a bucket (12.6 l) from the lagoon edge at low tide. The periwinkles were always collected from the same site, in order to reduce variability in biotype. The animals were transported to the laboratory and kept in holding glass tanks ( $30 \times 30 \times 30 \mathrm{~cm})$, which contained aerated lagoon water (6 l) at measured salinity that was variable depending on the time of year. Mud was collected from the same site and placed in the holding tank as substrate.

Other specimens, collected as described above, were left in holding tanks with a thin layer of sediment serving as substrate and food source for five or six days to allow them to acclimatize to laboratory and experimental conditions (relative humidity: $70 \pm 2 \%$; temperature: $26 \pm 2{ }^{\circ} \mathrm{C}$; salinity: $16 \%$ ) before using them in bioassays. The test animals were acclimatized to higher or lower salinities by diluting or concentrating the lagoon water by $2.5 \%$ once every 24 h; using dechlorinate tapwater or seawater of known salinity strength so that after the required number of changes, the desired predetermined test salinity (16\%) for all bioassays was achieved. This approach of gradual change in salinity was adopted to allow the periwinkles time to gradually adapt to the new salinity and so prevent a sudden osmotic change, which could result in stress that may distort responses to the test toxicants. T. fuscatus var radula of similar sizes depending on shell length (28 to $32 \mathrm{~mm}$ ) was selected for all experiments.

Test chemicals: The heavy metals investigated in this work were obtained as metallic salts of Fisons laboratory reagents, analar grades of the following types:
a. Copper as $\mathrm{CuSO}_{4} \cdot 5 \mathrm{H}_{2} \mathrm{O}$
b. Zinc as $\mathrm{ZnCO}_{3} .3 \mathrm{H}_{2} \mathrm{O}$
c. Lead as $\mathrm{Pb}\left(\mathrm{NO}_{3}\right)_{2}$
d. Cadmium as $3 \mathrm{Cd} \mathrm{SO} \mathrm{S}_{4} \cdot 8 \mathrm{H}_{2} \mathrm{O}$

The choice of heavy metals for this study was based on the available, common and abundant metals from the results of a chemical survey of industrial effluents that empty into the Lagos lagoon carried out by Oyewo (1998) and a survey of the Lagos lagoon water and sediment for heavy metals carried out by Otitoloju (2001).

\section{General bioassay technique}

Salinity of test media: All bioassays were carried out at salinity of $16 \%$. To achieve this, seawater was diluted with dechlorinate tap water to a salinity of $16 \%$ and served as test media, and also as dilution water for mixing toxicants. The animals were always acclimatized to $16 \%$. This salinity condition was used in all bioassays in order to standardize and simulate a typical brackish water medium, since changing salinity has been observed to affect toxicity. 
Preparation of substrate: In an attempt to simulate the natural environment of benthic test animals, sediment from the site of animal collection were used as substrates. The sediment also served as food for the test animals during the bioassays.

Preparation of test media including application of toxicant:

1) Single action bioassays: A pre-determined amount of each heavy metal compound was weighed (using an oertling 30TD top loading balance) and diluted with given volume of dechlorinate tapwater to obtain a stock solution of known strength. The resultant stock solution was serially diluted to obtain solutions of required concentrations.

2) Joint action bioassays: For each predetermined concentration of a mixture to be tested, the proportion of each constituent compound by weight of metallic element, dictated by the predetermined ratio of the mixture were computed and measured out into a conical flask and made up to the required test media volume by adding prepared brackish water (16\%) as diluent. The test media was then mixed thoroughly by stirring with glass rod for 2-3 min before transferring the mixture at the desired concentration into the appropriate bioassay container, already holding prepared sediment substrate.

\section{Bioaccumulation studies}

Bioaccumulation of heavy metals (Zn, $\mathrm{Pb}, \mathrm{Cu}$ and $\mathrm{Cd}$ ) by $T$. fuscatus exposed to sublethal concentration of single metal compounds: In this series of experiments, $T$. fuscatus was exposed to only sub-lethal concentrations (fractions of $96 \mathrm{~h} \mathrm{LC}_{50}$ values derived from experiments on acute toxicity of heavy metals against benthic animals as described in Otitoloju 2001) of selected metal salts as specified below. A total of 120 test animals were exposed per sublethal concentration or control in five replicates (24 periwinkles per replicate). Each bioassay container held a thin layer of standardized sediment substrate and test media at salinity of $16 \%$. In this series of bioassays that went on for 30 days in order to investigate the rate of bioaccumulation, the semi-static bioassay procedure was always adopted to avoid drastic changes in concentration of test media via evaporation and excessive reduction in dissolved oxygen level. In this semi-static procedure each test media was changed into a fresh solution at exactly the same concentration of heavy metal salt or untreated control as the case may be, once every four days, transferring the same exposed test animals into the freshly prepared test media over a 30 days period of experimentation.

At pre-determined time intervals (day 0, 4, 10, 20 and 30), four live T. fuscatus per replicate, making 20 per treatment including control were randomly selected, cleaned thoroughly with distilled water and placed in labeled polythene bags in which they were kept frozen awaiting digestion of the extracted whole animal tissues and analysis for test metals by atomic absorption spectrophotometer (AAS).

Sublethal concentrations under which bioaccumulation of test metals by $T$. fuscatus was investigated were as follows:

a. $\mathrm{Zn}\left(\mathrm{ZnCO}_{3} \cdot 3 \mathrm{H}_{2} \mathrm{O}\right)$ was tested at:

$8.310 \mathrm{mg} / \mathrm{l}\left(1 / 10^{\text {th }}\right.$ of the $\left.96 \mathrm{~h} \mathrm{LC}_{50}\right)$

$0.8317 \mathrm{mg} / \mathrm{l}\left(1 / 100^{\text {th }}\right.$ of the $\left.96 \mathrm{~h} \mathrm{LC}_{50}\right)$

and untreated control.

b. $\mathrm{Pb}\left(\mathrm{Pb}\left(\mathrm{NO}_{3}\right)_{2}\right)$ was tested at:

$37.077 \mathrm{mg} / \mathrm{l}\left(1 / 10^{\text {th }}\right.$ of the $\left.96 \mathrm{~h} \mathrm{LC}_{50}\right)$

$3.7077 \mathrm{mg} / \mathrm{l}\left(1 / 100^{\text {th }}\right.$ of the $\left.96 \mathrm{~h} \mathrm{LC}_{50}\right)$

and untreated control.

c. $\mathrm{Cu}\left(\mathrm{CuSO}_{4} \cdot 5 \mathrm{H}_{2} \mathrm{O}\right)$ was tested at:

$3.925 \mathrm{mg} / \mathrm{l}\left(1 / 10^{\text {th }}\right.$ of the $\left.96 \mathrm{~h} \mathrm{LC}_{50}\right)$

$0.3925 \mathrm{mg} / \mathrm{l}\left(1 / 100^{\text {th }}\right.$ of the $\left.96 \mathrm{~h} \mathrm{LC}_{50}\right)$

and untreated control.

d. $\mathrm{Cd}\left(3 \mathrm{CdSO}_{4} \cdot 8 \mathrm{H}_{2} \mathrm{O}\right)$ was tested at: $2.825 \mathrm{mg} / \mathrm{l}\left(1 / 10^{\text {th }}\right.$ of the $\left.96 \mathrm{~h} \mathrm{LC}_{50}\right)$ $0.2825 \mathrm{mg} / \mathrm{l}\left(1 / 100^{\text {th }}\right.$ of the $\left.96 \mathrm{~h} \mathrm{LC}_{50}\right)$ and untreated control. 
Bioaccumulation of heavy metals by $T$. fuscatus when exposed to sublethal concentrations of mixtures of heavy metal compounds: For this series of experiment, a semi-static bioassay procedure (APHA-AWWA-WPCF 1995) was adopted. T. fuscatus was exposed to sublethal concentrations of equitoxic multiple mixtures of $\mathrm{Zn}, \mathrm{Pb}, \mathrm{Cu}$ and $\mathrm{Cd}$. The multiple mixture consisted of sublethal concentration of each constituent metal salt, the computation of which was based on a pre-determined fraction $\left(1 / 10^{\text {th }}\right.$ and $\left.1 / 100^{\text {th }}\right)$ of the $96 \mathrm{~h} \mathrm{LC}_{50}$ values of the test metals obtained in single action experiments after Otitoloju (2001).

Details of the equitoxic metallic mixture (giving the amount of each constituent metal) to which the test animals $T$. fuscatus were exposed are given below.

a. Mixture based on $1 / 10^{\text {th }}$ of $96 \mathrm{~h} \mathrm{LC}_{50}$ of the respective metal salt at following concen-

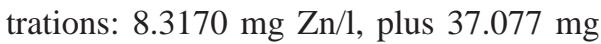
$\mathrm{Pb} / \mathrm{l}$, plus $3.925 \mathrm{mg} \mathrm{Cu} / \mathrm{l}$, plus $2.825 \mathrm{mg}$ $\mathrm{Cd} / \mathrm{l}$.

b. Mixture based on $1 / 100^{\text {th }}$ of $96 \mathrm{~h}$ LC50 of the respective metal salt at following concentrations: $0.8317 \mathrm{mg} \mathrm{Zn/l}$, plus $3.707 \mathrm{mg}$ $\mathrm{Pb} / \mathrm{l}$ plus, $0.392 \mathrm{mg} \mathrm{Cu} / \mathrm{l}$ plus, $0.282 \mathrm{mg}$ $\mathrm{Cd} / \mathrm{l}$.

c. Untreated control.

\section{Heavy metal analysis of animal samples for heavy metal content by Atomic Absorption Spectrophotometry (AAS)}

Digestion of samples: Whole animal samples (shell previously removed) of $T$. fuscatus were properly cleaned (by copiously rinsing all exposed and partially enclosed parts) with distilled water to remove debris, plankton and other external adherents before they were homogenized. A portion (10 g wet weight basis) from the homogenate of each animal was digested using a freshly prepared mixture 1:1 of hydrogen peroxide and perchloric acid (FAO/SIDA 1986).
AAS Determination of heavy metals in animal samples: All digestive contents were filtered through Whatman No.1 filter paper and made up to the mark in appropriate volumetric flasks ( $25 \mathrm{ml}$ ). The heavy metal content of each sample was then determined by comparing their absorbance with those of standard AAS solutions using an Alpha-4 Cathodeon Atomic Absorption Spectrophotometer.

Data analysis: Regression analysis (using Microsoft Excel 2000) was carried out to determine correlation co-efficient $\left(\mathrm{r}^{2}\right)$ between concentrations of test metals accumulated in the test animals $T$. fuscatus with period of exposure.

Bioaccumulation Ratio (BAR) was also estimated as the ratio of overall gain in metal tissue concentration after 30 days of exposure under joint accumulation studies to the overall gain in metal tissue concentration after 30 days under single accumulation studies. The aim of this computation was to establish a relationship between concentrations of metals accumulated under joint accumulation studies to the concentration accumulated when the metals were tested singly.

$$
\begin{gathered}
\text { Bioaccumulation } \\
\text { Ratio (BAR) }
\end{gathered}=\begin{aligned}
& \begin{array}{l}
\text { Overall gain under joint } \\
\text { accumulation studies }
\end{array} \\
& \begin{array}{l}
\text { Overall gain under single } \\
\text { accumulation studies }
\end{array}
\end{aligned}
$$

When,

$\mathrm{BAR}=1$ indicates similar gain in metal during joint and single bioaccumulation studies (non interactive)

BAR $>1$ indicates an increase in metal gained during joint accumulation studies (synergistic interaction).

$\mathrm{BAR}<1$ indicates a decrease in metal gained during joint bioaccumulation studies (antagonistic interaction).

Analysis of Variance (ANOVA) was used to compare several treatment means between the concentrations of metals accumulated either 
under the single and joint accumulation studies. Additionally, the t-test for evaluating significant difference between two treatment means was used to compare treatment means of concentration of metals accumulated under the joint action studies to the concentration accumulated when the metals were tested singly.

\section{RESULTS}

Physico-chemical characteristics of test medium during the bioaccumulation studies: During the bioassays, the dissolved oxygen content of test media remained higher than $5.5 \mathrm{mg} / \mathrm{l}$. The $\mathrm{pH}$, temperature and salinity remained fairly constant at $7.8 \pm 0.2,26 \pm 2{ }^{\circ} \mathrm{C}$ and $16.0 \pm 0.2 \%$, respectively, throughout the duration of the experiment.

Bioaccumulation of heavy metals (Zn, $\mathrm{Pb}, \mathrm{Cu}$ and $\mathrm{Cd}$ ) by $T$. fuscatus exposed to sublethal concentrations of metals in single and joint action laboratory studies.

Zinc (Zn): Post treatment analysis of whole body tissues of $T$. fuscatus showed that animals exposed to sublethal concentrations (0.4325 mg/l and $4.325 \mathrm{mg} / \mathrm{l})$ of $\mathrm{Zn}$ ions in the single action studies steadily accumulated higher quantities of the metal ions that were approximately two or four times higher than the levels accumulated in control animals, over a 30-day period (Table 1). Furthermore, the amount of $\mathrm{Zn}$ accumulated in the animal tissue was time $\left(r^{2}=0.818\right.$ and 0.9789 for the 0.4325 $\mathrm{mg} / \mathrm{l}$ and $4.325 \mathrm{mg} / \mathrm{l}$ test media, respectively, and test medium concentration dependent.

However, under the joint application studies, post treatment analysis of test animal tissues revealed that there were only minimal increment in the heavy metal content in exposed animals tissues compared to control animals (Table 1). Furthermore, the overall gain of Zn ion in the tissue of test animals after 30 days of exposure to the two test mixture concentrations (4.5885 mg/l and $45.885 \mathrm{mg} / \mathrm{l}$ ) was $6.64 \mu \mathrm{g} / \mathrm{g}$ and $22.64 \mu \mathrm{g} / \mathrm{g}$, respectively; and these values were lower than the amount $(11.07 \mu \mathrm{g} / \mathrm{g}$ and
$27.99 \mu \mathrm{g} / \mathrm{g}$, respectively) of Zn accumulated by $T$. fuscatus when it was exposed to test medium containing only $\mathrm{Zn}$ compound at the same test concentrations (Table 4 and Fig. 1). The computed bioaccumulation ratios were 0.60 and 0.81 (Table 5), thus indicating an antagonistic interaction between the metal components of the mixture in relation to $\mathrm{Zn}$ ion accumulation.

Statistical evaluation by Analysis of Variance (ANOVA) showed that there was no significant ( $>>.05)$ differences between the concentrations of the $\mathrm{Zn}$ ions detected in the animal tissues collected from the various test treatments (control, $0.4325 \mathrm{mg} / \mathrm{l}$ and $4.32 \mathrm{mg} / \mathrm{l}$ ) under the single or joint bioaccumulation studies. Furthermore, analysis based on the t-test for evaluating significant difference between two treatment means showed that there were no significant ( $\mathrm{p}>$.05) differences between the concentration of the $\mathrm{Zn}$ ions accumulated in the animal tissues under the single and joint bioaccumulation studies.

Lead (Pb): With regards to lead, analysis of animal tissues exposed to sublethal concentrations (3.9635 mg/l and $39.63 \mathrm{mg} / \mathrm{l}$ ) of $\mathrm{Pb}$ ions in the single action studies revealed that the animals accumulated measurable quantities of the metal that were approximately three-times above the levels accumulated by control animals, over the 30-day experimental

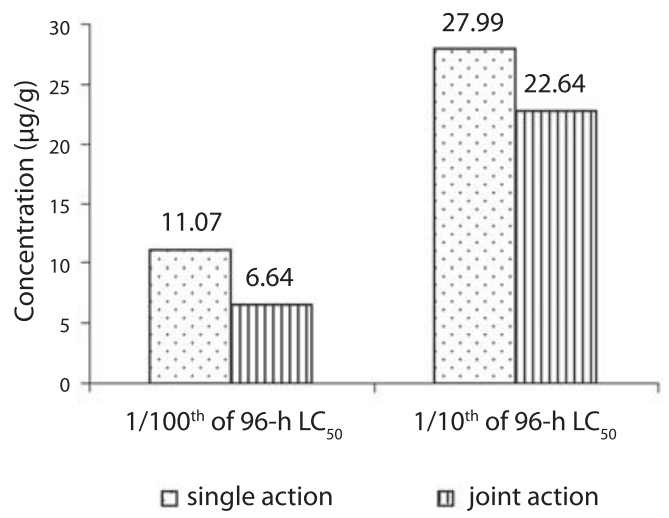

Fig. 1. Profile of the overall gain in heavy metal ( $\mathrm{Zn}$ ions) by $T$. fuscatus exposed to the test metals under single and joint bioaccumulation studies. 
TABLE 1

Accumulation of zinc by $\mathrm{T}$. fuscatus exposed to sub-lethal concentrations of the test metal under single and joint bioaccumulation studies

Mean concentrations of zinc ions in whole animal tissue

Overall [ $\mu \mathrm{g} \mathrm{g}^{-1}$ dry weight basis]

\begin{tabular}{|c|c|c|c|c|c|c|}
\hline & 0 day & 4 days & 10 days & 20 days & 30 days & \\
\hline \multicolumn{7}{|l|}{ Single Action } \\
\hline Untreated control & 4.29 & 7.37 & 8.09 & 7.82 & \multicolumn{2}{|l|}{7.29} \\
\hline${ }^{\mathrm{c}} 0.4325$ & 4.29 & 8.42 & 7.44 & 8.93 & \multicolumn{2}{|l|}{15.36} \\
\hline Net gain ${ }^{\mathrm{b}}$ & - & 4.13 & -0.98 & 1.49 & 6.43 & \multirow[t]{2}{*}{11.07} \\
\hline $\mathrm{d} 4.325$ & 4.29 & 7.84 & 12.27 & 26.48 & 32.28 & \\
\hline Net gain ${ }^{b}$ & - & 3.55 & 4.43 & 14.21 & 5.80 & 27.99 \\
\hline \multicolumn{7}{|l|}{ Joint Action } \\
\hline Untreated control & 5.62 & 8.26 & 7.71 & 9.26 & \multicolumn{2}{|l|}{7.73} \\
\hline c0.4325 & 5.62 & 8.37 & 8.89 & 9.32 & \multicolumn{2}{|l|}{12.26} \\
\hline Net gain ${ }^{b}$ & - & 2.75 & 0.52 & 0.43 & 2.94 & \multirow[t]{2}{*}{6.64} \\
\hline $\mathrm{d} 4.325$ & 5.62 & 9.49 & 11.38 & 22.16 & 28.26 & \\
\hline Net gain ${ }^{b}$ & - & 3.87 & 1.89 & 10.78 & 6.1 & 22.64 \\
\hline \multicolumn{7}{|c|}{$\begin{array}{l}\text { a Overall net gain= concentration in animal after 30days-concentration in animal at zero day. } \\
\text { b Net gain-difference in concentration between the immediate preceding days of harvesting, eg 4-0 day, 10-4 day, etc. } \\
\text { c } 1 / 100^{\text {th }} 96 \mathrm{~h} \mathrm{LC}_{50} \text { values of the metal ions in the test compounds. } \\
\text { d } 1 / 10^{\text {th }} 96 \mathrm{~h} \mathrm{LC} \mathrm{LC}_{50} \text { values of the metal ions in the test compounds. }\end{array}$} \\
\hline
\end{tabular}

period (Table 2). The amount of $\mathrm{Pb}$ accumulated in the animal tissue was also found to be time $\left(r^{2}=0.8859\right.$ and 0.9715 for $3.9635 \mathrm{mg} / \mathrm{l}$ and $39.635 \mathrm{mg} / \mathrm{l}$ test media, respectively) and test medium concentration dependent. Similar observation was also recorded under the joint action studies (Table 2).

In the presence of other metals, ie. under joint action studies, the total amount of $\mathrm{Pb}$ ion accumulated in animals exposed to each of the two sublethal concentrations (4.5885 mg/l and $45.885 \mathrm{mg} / \mathrm{l}$ ) of metal mixtures was $287.95 \mu \mathrm{g} / \mathrm{g}$ and $459.56 \mu \mathrm{g} / \mathrm{g}$ respectively (Table 2); and these accumulated values were approximately two times and 1.4 times higher than the amounts of (144.05 $\mu \mathrm{g} / \mathrm{g}$ and $339.03 \mu \mathrm{g} / \mathrm{g}$, respectively) $\mathrm{Pb}$ ion accumulated under the single action studies (Table 5, Fig. 2). The computed bioaccumulation ratios were 2.0 and 1.36 (Table 5), thus indicating a synergistic interaction between

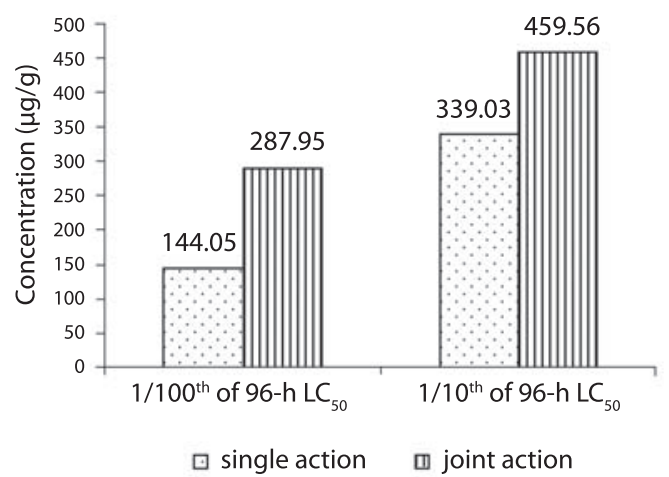

Fig. 2. Profile of the overall gain in heavy metal ( $\mathrm{Pb}$ ions) by $T$. fuscatus exposed to the test metals under single and joint bioaccumulation studies.

the metal components of the mixture in relation to the $\mathrm{Pb}$ ion accumulation.

Statistical evaluation by Analysis of Variance (ANOVA) showed that there were 
TABLE 2

Accumulation of lead by $\mathrm{T}$. fuscatus exposed to sub-lethal concentrations of the test metal under single and joint bioaccumulation studies

Mean concentrations of lead ions in whole animal tissue

Overall [ $\mu \mathrm{g} \mathrm{g}^{-1}$ dry weight basis]

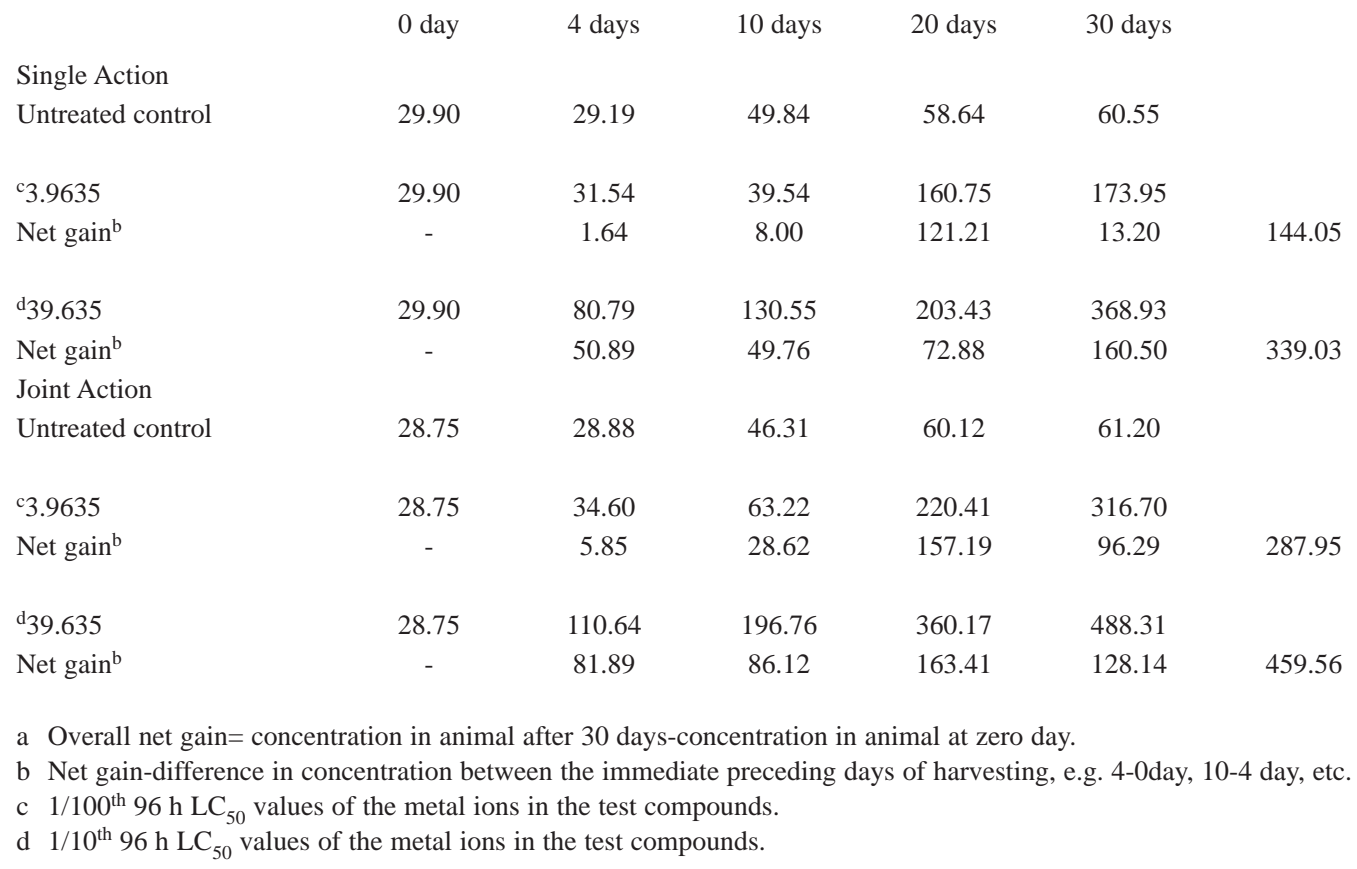

significant $(\mathrm{p}<.05)$ differences between the concentrations of the $\mathrm{Pb}$ ions detected in the animal tissues collected from the various test treatments (control, $3.9635 \mathrm{mg} / \mathrm{l}$ and $39.635 \mathrm{mg} / \mathrm{l}$ ) under the single or joint bioaccumulation studies. Furthermore, analysis based on the t-test for evaluating significant difference between two treatment means showed that there were no significant ( $\mathrm{p}>.05)$ differences between the concentration of the $\mathrm{Pb}$ ions accumulated in the animal tissues under the single and joint bioaccumulation studies.

Copper (Cu): Post treatment analysis of whole body tissues of $T$. fuscatus showed that the animals exposed to sublethal concentrations $(0.1021 \mathrm{mg} / \mathrm{l}$ and $1.0206 \mathrm{mg} / \mathrm{l})$ of the $\mathrm{Cu}$ compound accumulated measurable quantities of the metal ions that were approximately two or three higher than the level accumulated by animals in untreated control media (Table 3). Furthermore, at the end of the 30-day exposure period, the amount of $\mathrm{Cu}$ accumulated by the exposed animals fluctuated significantly over the 30-day exposure period and there were no significant positive correlations between the amount of $\mathrm{Cu}$ accumulated by the animals with respect to time $\left(\mathrm{r}^{2}=0.1351\right.$ and 0.3986 for $0.1021 \mathrm{mg} / \mathrm{l}$ and $1.021 \mathrm{mg} / \mathrm{l}$ test media, respectively) and test medium concentration. Similar observation was also recorded under the joint action studies (Table 3).

In the presence of other metals, ie under joint action studies, the total amount of $\mathrm{Cu}$ ion accumulated in animals exposed to each of the two sublethal concentrations (4.5885 $\mathrm{mg} / \mathrm{l}$ and $45.885 \mathrm{mg} / \mathrm{l}$ ) of metal mixtures were $0.62 \mu \mathrm{g} / \mathrm{g}$ and $1.08 \mu \mathrm{g} / \mathrm{g}$, respectively, compared to $0.44 \mu \mathrm{g} / \mathrm{g}$ and $7.23 \mu \mathrm{g} / \mathrm{g}$ respectively of $\mathrm{Pb}$ ion accumulated by animals exposed to 
corresponding concentrations under the single action studies (Table 5, Fig. 3). The computed bioaccumulation ratios were 1.41 and 0.15 (Table 5), thus indicating varying interactions at different level of $\mathrm{Cu}$ concentrations in the mixture.

Statistical evaluation by Analysis of Variance (ANOVA) showed that there were no significant ( $\mathrm{p}>.05)$ differences between the concentrations of the $\mathrm{Cu}$ ions detected in the animal tissues collected from the various test treatments (control, $0.1021 \mathrm{mg} / \mathrm{l}$ and $1.021 \mathrm{mg} / \mathrm{l}$ ) under the single or joint bioaccumulation studies. Furthermore, analysis based on the t-test for evaluating significant difference between two treatment means showed that there were no significant ( $>>.05)$ differences between the concentrations of the $\mathrm{Cu}$ ions accumulated in the animal tissues under the single and joint bioaccumulation studies.

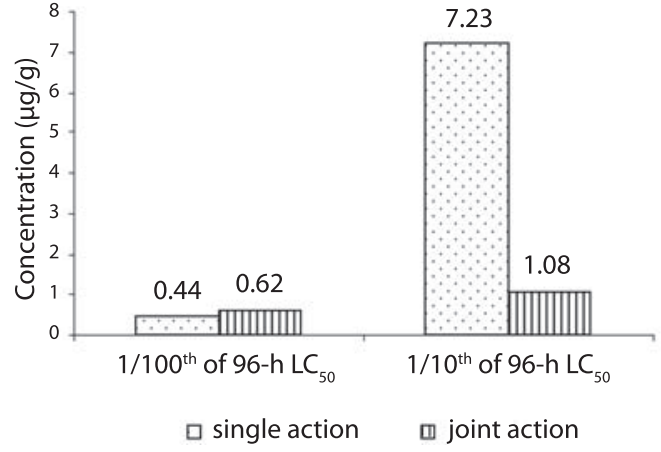

Fig. 3. Profile of the overall gain in heavy metal (Cu ions) by $T$. fuscatus exposed to the test metals under single and joint bioaccumulation studies.

Cadmium (Cd): Post treatment analysis of whole body tissues of $T$. fuscatus showed that there were little differences between the amount of Cd accumulated by the animals exposed to

TABLE 3

Accumulation of copper by $\mathrm{T}$. fuscatus exposed to sub-lethal concentrations of the test metal under single and joint bioaccumulation studies

Mean concentrations of copper ions in whole animal tissue [ $\mu \mathrm{g} \mathrm{g}^{-1}$ dry weight basis]
Overall

net gain ${ }^{\mathrm{a}}$
0 day
4 days
10 days
20 days
30 days

Single Action

Untreated control

$$
11.04
$$

14.63

17.62

10.69

6.55

${ }^{\mathrm{c}} 0.1021$

11.04

Net gain ${ }^{b}$

$-$

${ }^{\mathrm{d}} 1.021$

Net gain ${ }^{\mathrm{b}}$

11.04

Joint Action

Untreated control

10.02

12.96

13.05

0.09

21.69

18.89

$-2.8$

14.12

16.93

9.01

14.96

$-1.01$

5.95

8.17

$-1.85$

12.26

4.09

10.02

\subsection{5}

$-5.4$

12.39

$-6.5$

10.22

8.29

$-6.67$

15.43

3.17
Net gain ${ }^{\mathrm{b}}$

a Overall net gain= concentration in animal after 30 days-concentration in animal at zero day.

b Net gain-difference in concentration between the immediate preceding days of harvesting, eg 4-0 day, 10-4 day, etc.

c $1 / 100^{\text {th }} 96 \mathrm{~h} \mathrm{LC}_{50}$ values of the metal ions in the test compounds.

d $1 / 10^{\text {th }} 96 \mathrm{~h} \mathrm{LC}_{50}$ values of the metal ions in the test compounds. 
the treated media $(0.0904 \mathrm{mg} / \mathrm{l}$ and $0.904 \mathrm{mg} / \mathrm{l})$ and the control animals (Table 4). Although the concentration of $\mathrm{Cd}$ accumulated by the test animals was not substantial, there were significant and positive correlations between the amount of $\mathrm{Cd}$ accumulated by $\mathrm{T}$. fuscatus with time of exposure $\left(r^{2}=0.966\right.$ and 0.9712 for $0.0904 \mathrm{mg} / \mathrm{l}$ and $0.904 \mathrm{mg} / \mathrm{l}$ test media, respectively). Similar observation was also recorded under the joint action studies (Table 4).

In the presence of other metals i.e. under joint action studies, the total amount of $\mathrm{Cd}$ ion accumulated in animals exposed to each of the two sublethal concentrations (4.5885 $\mathrm{mg} / \mathrm{l}$ and $45.885 \mathrm{mg} / \mathrm{l}$ ) of metal mixtures were $0.29 \mu \mathrm{g} / \mathrm{g}$ and $0.79 \mu \mathrm{g} / \mathrm{g}$ respectively; and these values were approximately three times and two times lower than the amounts of $0.56 \mu \mathrm{g} / \mathrm{g}$ and $1.24 \mu \mathrm{g} / \mathrm{g}$ of Cd accumulated by $T$. fuscatus when exposed to test medium containing only
Cd compound at corresponding concentrations (Table 5 and Fig. 4). The computed bioaccumulation ratios were 0.52 and 0.64 (Table 5), thus indicating an antagonistic interaction between the metal components of the mixture in relation to the Cd accumulation.

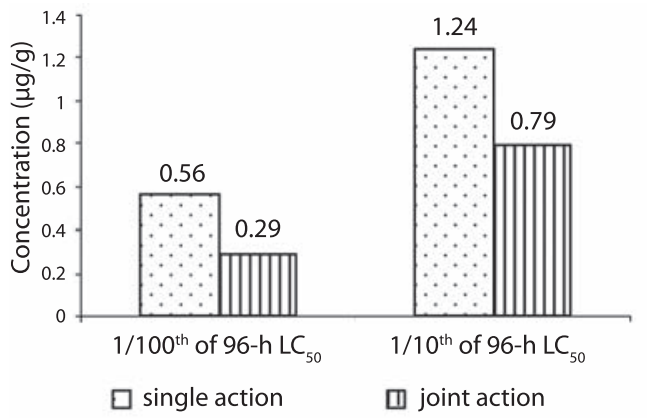

Fig. 4. Profile of the overall gain in heavy metal (Cd ions) by $T$. fuscatus exposed to the test metals under single and joint bioaccumulation studies.

TABLE 4

Accumulation of cadmium by $\mathrm{T}$. fuscatus exposed to sub-lethal concentrations of the test metal under single and joint bioaccumulation studies

Mean concentrations of cadmium ions in whole animal tissue [ $\mu \mathrm{g} \mathrm{g}^{-1}$ dry weight basis]

0 day $\quad 4$ days 10 days 20 days 30 days

Single Action

Untreated control

0.02

0.02

0.03

0.06

0.08

${ }^{\mathrm{c}} 0.0904$

Net gain ${ }^{b}$

0.02

0.03

0.01

0.02

0.26

0.24

0.020

0.025

0.033

0.07

0.05

0.020

0.024

0.004

0.11

0.08

0.91

0.65

0.09

0.02

0.360

0.336

0.380

0.020

0.32

0.21

1.22

0.31

0.054

0.12

0.03

0.19

0.810

0.430

Overall net gain ${ }^{\mathrm{b}}$

b Overall net gain= concentration in animal after 30 days-concentration in animal at zero day.

b Net gain-difference in concentration between the immediate preceding days of harvesting, eg 4-0 day, 10-4 day, etc.

c $1 / 100^{\text {th }} 96 \mathrm{~h} \mathrm{LC}_{50}$ values of the metal ions in the test compounds.

d $1 / 10^{\text {th }} 96 \mathrm{~h} \mathrm{LC}_{50}$ values of the metal ions in the test compounds. 
TABLE 5

Comparison of the overall gain* in heavy metals by T. fuscatus exposed to the metals under single and joint bioaccumulation studies in laboratory bioassays

\begin{tabular}{|c|c|c|c|}
\hline Treatments/Metals & $\begin{array}{l}\text { overall gain* of metal in single } \\
\text { bioaccumulation studies }\left[\mu \mathrm{g} \mathrm{g}^{-1}\right]\end{array}$ & $\begin{array}{l}\text { overall gain* of metal in joint } \\
\text { bioaccumulation studies [ } \mu \mathrm{g} \mathrm{g}^{-1} \text { ] }\end{array}$ & $\mathrm{BAR}^{* *}$ \\
\hline \multicolumn{4}{|l|}{$1 / 100^{\mathrm{TH}}$ of $96-\mathrm{h}$ LC50 } \\
\hline $\mathrm{Zn}$ & 11.07 & 6.64 & 0.60 \\
\hline $\mathrm{Pb}$ & 144.05 & 287.95 & 2.0 \\
\hline $\mathrm{Cu}$ & 0.44 & 0.62 & 1.41 \\
\hline $\mathrm{Cd}$ & 0.56 & 0.29 & 0.52 \\
\hline \multicolumn{4}{|l|}{$1 / 10^{\mathrm{TH}}$ of $96-\mathrm{h}$ LC50 } \\
\hline $\mathrm{Zn}$ & 27.99 & 22.64 & 0.81 \\
\hline $\mathrm{Pb}$ & 339.03 & 459.56 & 1.36 \\
\hline $\mathrm{Cu}$ & 7.23 & 1.08 & 0.15 \\
\hline Cd & 1.24 & 0.79 & 0.64 \\
\hline
\end{tabular}

a Overall gain= concentration in animal after 30 days-concentration in animal at zero day

b Bioaccumulation Ratio [BAR]= overall gain under joint accumulation studies overall gain under single accumulation studies

$\mathrm{BAR}=1$ indicates similar gain in metal during joint \& single bioaccumulation studies [additive]

$\mathrm{BAR}>1$ indicates an increase in metal gained during joint bioaccumulation studies [synergism]

$\mathrm{BAR}<1$ indicates a decrease in metal gained during joint bioaccumulation studies [antagonism]

Statistical evaluation by Analysis of Variance (ANOVA) showed that there were no significant ( $\mathrm{p}>.05)$ differences between the concentrations of the $\mathrm{Cd}$ ions detected in the animal tissues collected from the various test treatments (control, $0.0904 \mathrm{mg} / \mathrm{l}$ and 0.904 $\mathrm{mg} / \mathrm{l}$ ) under the single or joint bioaccumulation studies. Furthermore, analysis based on the t-test for evaluating significant difference between two treatment means showed that there were no significant ( $\mathrm{p}>.05)$ differences between the concentration of the Cd ions accumulated in the animal tissues under the single and joint bioaccumulation studies.

\section{DISCUSSION}

In the single action studies, the exposure of $T$. fuscatus to sublethal concentrations of $\mathrm{Zn}$, $\mathrm{Pb}$ or $\mathrm{Cu}$ resulted in a steady increase in the body tissue concentration of the metals to levels that were two to six times higher than in control animals. The observation of increased concentration of these metals in animals exposed to sublethal concentrations of the metals in single action laboratory studies is well established (Bryan and Langston 1992, Baron 1995, Oyewo 1998). The bioaccumulation of heavy metals in animal tissues occurs as a result of competing rates of chemical uptake and excretion. Furthermore, the synthesis of low-molecular weight proteins, eg metallothionein which form complexes with the metal ions, as well as the formation of encapsulated metal granules in tissues of exposed animals have also been reported to be responsible for metal accumulation in some aquatic mollusk (Langston and Zhou 1987, George 1989, Clark 1992).

It must however be noted that the exposure of $T$. fuscatus to the sublethal concentrations (3.92 $\mathrm{mg} / \mathrm{l}$ and $0.392 \mathrm{mg} / \mathrm{l}$ ) of $\mathrm{Cu}$ revealed that the amount of $\mathrm{Cu}$ accumulated in the tissues of the exposed animals fluctuated significantly over the experimental period. Furthermore, exposure of the test animals to sublethal concentration of Cadmium resulted in minimal changes in the body tissue concentration of cadmium in the exposed animals over the 30day experimental period, indicating the ability 
of the animal to excrete cadmium rapidly before it builds up at the test concentration.

The exposure of the animals to the test sublethal concentrations of heavy metals (Zn, $\mathrm{Pb}, \mathrm{Cu}$ and $\mathrm{Cd}$ ) mixtures, in order to demonstrate the influence of the metals on the individual rate and pattern of bioaccumulation revealed that there were interactions between the constituent metals when applied jointly against $T$. fuscatus. These interactions resulted either an increase or decrease on overall concentrations of the metals accumulated in the animal tissues at steady state when compared to results obtained in the single action studies. For instance, the concentrations of $\mathrm{Zn}, \mathrm{Cu}$ and $\mathrm{Cd}$ ions accumulated by the periwinkle were found to be about two-seven times lower than the concentrations of the same metals in exposed animals during the single actions studies, indicating an antagonistic interaction between the metals. Interestingly, this observation of antagonistic interactions between the test metals is in conformity with an observation of reduction in toxicity of these metals when applied in mixtures against T. fuscatus (Otitoloju 2001).

However, with regards to $\mathrm{Pb}$ ion accumulation, the concentration of the metal accumulated by $T$. fuscatus over the 30-day experimental period was found to be higher (about two times) than the concentration of the metal accumulated over a similar period when the animal was exposed to $\mathrm{Pb}$ acting singly. This observation also corroborated the results of Otitoloju (2001) who reported an enhancement in the toxicity of $\mathrm{Pb}$ compound against $T$. fuscatus when applied jointly with $\mathrm{Zn}, \mathrm{Cu}$ ad Cd compounds. The mechanism(s) responsible for the enhanced or reduced bioaccumulation of the test metals when applied jointly against T. fuscatus is therefore suspected to be as a result of interference with penetrability of the metals, competition for binding sites or the formation of metal complexes which may be easier (or not) to excrete. This should therefore merit future investigations in order to establish more accurately the mechanism(s) responsible for the antagonistic interactions between these metals when tested against $T$. fuscatus.
The practical significance of this joint bioaccumulation study is that it provides an important exploratory bioassay which could assist in understanding the mechanism(s) responsible for the type of interactions existing between heavy metal types when applied jointly in toxicity studies. Furthermore, results of metal interactions and the subsequent reduction on the concentration of the metals bioaccumulated in exposed animals may be useful in the management of metal contaminated water bodies in a similar way in which such observation of antagonistic interaction between mercury $(\mathrm{Hg})$ and selenium (Se) was exploited by Paulsson and Lundbergh (1991) on the treatment of mercury contaminated fishes in Swedish Lakes.

\section{ACKNOWLEDGMENTS}

The author is grateful A. Pat of ABM Laboratories for analysis of samples and K. N. Junaid of the National Reference Lab., Federal Ministry of Environment, Nigeria, for quality assurance tests carried out.

\section{RESUMEN}

La mayoría de los análisis de laboratorio sobre toxicidad y bioacumulación de metales pesados se han concentrado en la acumulación individual de los iones metálicos en los organismos de prueba expuestos a ellos. Sin embargo, bajo condiciones naturales del ambiente, los metales nunca se presentan en forma aislada y deben interactuar unos con otros, justificando así la necesidad de estudiar el efecto de la aplicación conjunta de metales en animales de prueba. En este estudio la exposición de Tympanotonus fuscatus a concentraciones subletales (0.1-0.01 de $96 \mathrm{~h}$ $\mathrm{LC}_{50}$ ) de metales pesados reveló que la bioacumulación varía según el tipo de metal, el período de exposición y la concentración en el medio de prueba. Mientras los iones de $\mathrm{Zn}$ y $\mathrm{Pb}$ incrementaron gradualmente su acumulación al pasar el tiempo, las cantidades de $\mathrm{Cu}$ fluctuaron regularmente durante los 30 días del experimento. Los niveles de $\mathrm{Zn}$, $\mathrm{Cu}$ y $\mathrm{Cd}$ bioacumulados durante los 30 días del experimento son de dos a seis veces menores (con un rango de bioacumulación de 0.15-0.81) que los que se obtienen por la exposición a los metales en forma individual. Por el contrario, la acumulación de $\mathrm{Pb}$ aumentó al doble (rango de bioacumulación 1.36-2.0). 
Palabras clave: bioacumulación, acción conjunta, metales, antagonismo, sinergismo.

\section{REFERENCES}

APHA-AWWA-WPCF. 1995. Standard methods for the examination of water and wastewater. American Public Health Association, USA.

Baron, M.G. 1995. Bioaccumulation and bioconcentration in aquatic organisms, p. 652-662. In D.H. Hoffman, B.A. Rattner, B.A. Jr. Burton \& G.A. Jr. Cairns (eds.). Handbook of Ecotoxicology. CRC-Lewis, England.

Bryan, G.W. \& W.J. Langston. 1992. Bioavailability, accumulation and effects of Heavy metals in sediments with special reference to United Kingdom estuaries: A review. Env. Poll. 76: 89-131.

Clark, R.B. 1992. Marine Pollution. Oxford, England. 169 p.

FAO/SIDA. 1986. Manual of methods in aquatic environmental research, part 9. Analyses of metals and organochlorines in fish. FAO, Italy. 212 p.

Franklin, N.M., J.L. Stauber, R.P. Lim \& P. Petocz. 2002. Toxicity of metal mixtures to a tropical freshwater alga (Chlorella sp.): The effect of interactions between Copper, Cadmium and Zinc on metal cell binding and uptake. Environ. Toxicol. Chem. 21: 2412-2422.

George, S.G. 1989. Cadmium effects on place liver xenobiotic and metal detoxication systems: dose-response. Aquat. Toxicol. 15: 303-310.

Kiffney, P.M. \& W.H. Clement. 1993. Bioaccumulation of heavy metals by benthic Invertebrates at the Arkansas River, Colorado. Environ. Toxicol. Chem. 12: 1507-1517.

Langston, W.J. \& M. Zhou. 1987. Cadmium accumulation, distribution and metabolism and in the gastropod Littorina littorea: the role of metal-binding proteins. J. Mar. Biol. Ass. UK 67: 585-601.

Otitoloju, A.A. 2001. Joint action toxicity of heavy metals and their bioaccumulation by benthic animals of the Lagos lagoon. Ph.D Thesis, University of Lagos, Nigeria. 231 p.

Otitoloju, A.A. 2002. Evaluation of the joint-action toxicity of binary mixtures of heavy metals against the mangrove periwinkle Tympanotonus fuscatus var radula (L.). Ecotoxicol. Environ. Saf. 53: 404-415.

Otitoloju, A.A. 2003. Relevance of joint action toxicity evaluations in setting realistic environmental safe limits of heavy metals. JEM 67: 121-128.

Otitoloju, A.A. \& K.N. Don-Pedro. 2003. Bioaccumulation of heavy metals ( $\mathrm{Zn}, \mathrm{Pb}, \mathrm{Cu}$ and $\mathrm{Cd}$ ) by Tympanotonus fuscatus var radula (L.) exposed to sublethal concentrations in laboratory bioassays. WAJAE 3: 17-29.

Otitoloju, A.A. \& K.N. Don-Pedro. 2004. Integrated laboratory and field assessments of heavy metals accumulation in edible periwinkle, Tympanotonus fuscatus var radula (L.). Ecotoxicol. Environ. Saf. 57: 354-362.

Oyewo, E.O. 1998. Industrial Sources and distribution of Heavy Metals in Lagos Lagoon and their biological Effects on Estuarine animals. Ph.D Thesis, University of Lagos, Nigeria. 274 p.

Panigrahi, A.K. \& B.N. Misra. 1980. Toxicological effects of a sub-lethal concentration of inorganic mercury on the freshwater fish Tilapia mossambica, Peters. Arch. Toxicol. 44: 269-278.

Paulsson, K. \& K. Lundbergh. 1991. Treatment of mercury contaminated fish by Selenium addition. Wat. Air Soil Pollut. 56: 833-841.

Sastry, K.V. \& V. Shukla. 1993. Uptake and distribution of Cadmium in tissues of Channa puntatus. J. Env. Biol. 14: 137-142.

Wright, D.A. \& C.D. Zamuda. 1987. Copper accumulation by two bivalve mollusks: salinity effect is independent of cupric ion activity. Mar. Environ. Res. 23: $1-14$.

Wright, D.A., P.M. Welbourn \& A.V.M. Martin. 1991. Inorganic and organic mercury uptake and loss by the crayfish, Orconectes Propinquus. Wat. Air Soil Pollut. 56: 697-708. 